\title{
Marco Maulu, Fra attrazione e distacco: il Medioevo illuminato di Jean Baptiste La Curne de Sainte-Palaye
}

\author{
Maria Colombo Timelli
}

\section{(2) OpenEdition}

10 Journals

\section{Édition électronique}

URL : http://journals.openedition.org/studifrancesi/7816

DOI : 10.4000/studifrancesi.7816

ISSN : 2421-5856

Éditeur

Rosenberg \& Sellier

\section{Édition imprimée}

Date de publication : 1 juillet 2009

Pagination : 368

ISSN : 0039-2944

\section{Référence électronique}

Maria Colombo Timelli, « Marco Maulu, Fra attrazione e distacco: il Medioevo illuminato di Jean Baptiste La Curne de Sainte-Palaye », Studi Francesi [En ligne], 158 (LIII | II) | 2009, mis en ligne le 30 novembre 2015, consulté le 13 janvier 2021. URL : http://journals.openedition.org/studifrancesi/7816; DOI : https://doi.org/10.4000/studifrancesi.7816

Ce document a été généré automatiquement le 13 janvier 2021.

\section{(c)}

Studi Francesi è distribuita con Licenza Creative Commons Attribuzione - Non commerciale - Non opere derivate 4.0 Internazionale. 


\title{
Marco Maulu, Fra attrazione e distacco: il Medioevo illuminato di Jean Baptiste La Curne de Sainte-Palaye
}

\author{
Maria Colombo Timelli
}

\section{RÉFÉRENCE}

MARCO MAULU, Fra attrazione e distacco: il Medioevo illuminato di Jean Baptiste La Curne de Sainte-Palaye, in Recensioni e biografie. Libri e maestri, a cura di Paolo MANINCHEDDA, Cagliari, CUEC, 2007, pp. 223-249.

1 Nul doute que La Curne de Sainte-Palaye mérite pleinement le titre de «maestro» dans le domaine des études médiévales, et c'est en tant que tel qu'il trouve une place dans un recueil consacré aux maîtres de la philologie romane.

2 À travers une lecture attentive et la mise en parallèle des Mémoires sur l'ancienne chevalerie (1759), l'Histoire Littéraire des Troubadours (1774), le Glossaire de la langue françoise (publié posthume vers la fin du XIX siècle), M.M. souligne le profond intérêt de cet érudit pour le Moyen Âge, intérêt qui ne s'est jamais démenti et qui comprend néanmoins deux aspects apparemment contradictoires: fascination et mise à distance. Attentif aux documents originaux, capable de les déchiffrer, conscient de l'importance de la collation, à la recherche toujours du texte "authentique», La Curne ne peut que fasciner à son tour les médiévistes d'aujourd'hui, en quête de leurs racines.

Deux remarques en marge de cet article: le Mémoire a fait l'objet d'une étude remarquable de Keith Busby (An Eighteenth-Century Plea on Behalf of the Medieval Romances: La Curne de Sainte-Palaye's 'Mémoire concernant la lecture des anciens romans de chevalerie, «Studies on Medievalism» [Oxford, Ohio], 3, 1987, pp. 55-69), étude que M.M. ne cite pas, et qui lui aurait rendu service; d'autre part, M.M. ne prend pas en compte le fait que, sauf exception, les extraits de La Curne sont restés à l'état de manuscrits et que, par conséquent, leur influence sur la réception de la littérature médiévale peut 
être considérée quasiment nulle: lecteurs et «curieux» de la fin du XVIII siècle ont eu accès aux œuvres du Moyen Âge à travers les réécritures de Paulmy, Tressan, ou par la Bibliothèque Universelle des Romans. 